\title{
The interaction of UCS intensity and intertrial interval in avoidance learning '
}

PAUL S. KURTZ 2 AND JAMES N. SHAFER WEST VIRGINIA UNIVERSITY

In $a 3$ by 3 factorial design, 27 rats were given 50 trials of avoidance conditioning in a shuttlebox. The main effects of shock $(.2, .4$, and $.8 \mathrm{~mA})$ and of intertrial interval $(15,30$, $60 \mathrm{sec}$ ), as well as the interaction, were significant. Ss with $.2 \mathrm{~mA}$ avoided equally well with all ITIs, $.4 \mathrm{~mA}$ best at 30 sec ITI, and . $8 \mathrm{~mA}$ at $60 \mathrm{sec}$.

Evidence from recent studies has been accumulating to support the generalization "that the acquisition of a discriminated avoldance response is inversely related to shock intensity" (D'Amato, Fazzaro, \& Etkin, 1967). This finding is in apparent contradiction to several studies which reported the incremental effects of shock intensity upon avoidance acquisition (Kimble, 1955; Brush, 1957). However, the positive relation reported in these studies appears rather distinctly related to the required intensity level to induce escape responding, as D'Amato et al have indicated.

An inverse relationship between shock intensity and rate of avoidance learning would appear to be contrary to the hypothesis, derivable from two-factor theory, that increased shock intensity should lead to greater fear and, thereby on avoidance trials, to greater fear reduction and faster avoidance learning. This prediction from two-factor theory, however, assumes a rather uncomplicated relationship between the two processes. The present experiment examines the role of shock intensity from the view that with an increase in shock the accompanying increase in fear may become so great that little or no fear reduction occurs during the intertrial interval. Indirect support for this position is provided by the investigations showing an increase in the rate of avoidance learning. with increased intertrial intervals (Murphy \& Miller, 1956; Levine \& England, 1960; Brush, 1962). The results have been interpreted by Brush (1962) to indicate that greater reinforcement (fear reduction) accrues to the avoidance response with increasing intertrial intervals. Assuming greater fear at higher shock levels it would be predicted that shock intensity interacts with ITI having the greatest effect at short ITI, i.e., the shorter the ITI, the more pronounced the effects at a high intensity of shock. The present experiment investigates the interaction of shock intensity and ITI.

Method

Twenty-seven Long-Evans female rats 125 days of age selected from the colony maintained at West Virginia University Animal Behavior Laboratory served as Ss. Since adaptation to the apparatus has been shown to facilitate performance (Zerbolio et al, 1965), Ss were placed in the shuttle boxes $30 \mathrm{~min}$ prior to testing.

The Ss were tested on four identical Miller-Mowrer type shuttleboxes 30 in. long, 10-1/2 in. wide, and 6 in. high. A light source, producing a $10 \mathrm{ft}-\mathrm{c}$ change in illumination at the grid, projected through two flashed opal panels of glass in the ceiling at the ends of the boxes served as the CS. The UCS, electric shock, was scrambled by a Davis 225 scrambler.

The experimental design was a 3 by 3 factorial with three replications in each cell. Shock was supplied by a Davis 276 Shock Power source adjusted to $140 \mathrm{~V}$. A rotary switch directed the current through one of three resistances, $100 \mathrm{k}, 220 \mathrm{k}$, or $470 \mathrm{k}$ ohms. The current drawn by the animal under these conditions approximated .8 $\mathrm{mA}, .4 \mathrm{~mA}$, and .2 $\mathrm{mA}$, respectively, and hence is referred to by these values. Fixed ITIs of $15 \mathrm{sec}, 30 \mathrm{sec}$, and $60 \mathrm{sec}$ were controlled by $E$ as read from a timer. The experiment was conducted in a single session of 50 trials. The CSUCS interval was 5 sec unless $E$ prevented a response contingent shock (Kurtz \& Shafer, 1966) by opening the shock circuit when $S$ began a response late in the CS-UCS interval. If $S$ continued responding sufficiently to cross the center line, shock was not administered. If and when $S$ ceased responding short of crossing the center line, the shock circuit was closed. In all cases, the CS was terminated when $S$ crossed the center of the shuttlebox. If this occurred prior to onset of shock, it was scored an avoidance and if after onset of shock it was scored an escape response. In the latter case, shock also was terminated with the CS.

\section{Results and Discussion}

The analysis of variance indicates significant main effects due to shock $(p<.001)$ and ITI $(p<.05)$ with longer ITI and decreased shock intensity facilitating avoidance learning. In addition, the results show a significant interaction ( $p<.05$ ) between shock intensity and ITI. This interaction as shown in Fig. 1 is largely due to the fact that ITI had no effect at the .2 mA shock level as compared with the higher shock levels. The .4 $\mathrm{mA}$ shock resulted in improved performance at $30 \mathrm{sec}$ over $15 \mathrm{sec}$ ITI and the $.8 \mathrm{~mA}$ shock level yielded improved performance with each increase in ITI.

The interaction of shock intensity and ITI is consistent with the view that the inverse relationship between shock intensity and active avoidance learn- 


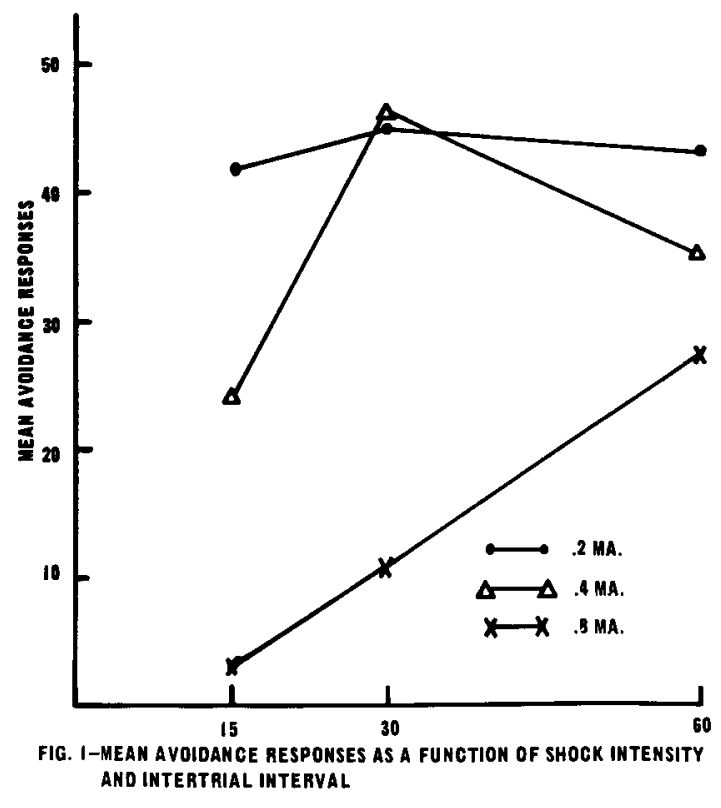

ing occurs as the result of the increased fear induced by the more intense shock. Although no firm conclusions can be drawn from the present experiment, the form of the curve for the $.8 \mathrm{~mA}$ shock group suggests that with an ITI sufficiently long shock intensity would not influence avoidance learning. The inverse relationship between shock intensity and avoidance learning reported by Moyer \& Korn (1964) was obtained at an ITI averaging $20 \mathrm{sec}$ (range $10-30 \mathrm{sec}$ ). The results of the present experiment shows the same relationship most clearly at the 15 sec ITI.

To account for the inverse relationship between shock intensity and avoidance learning it has been suggested (Johnson \& Church, 1965; D'Amato \& Fazzaro, 1966) that the more intense shock results in greater conditioning of responses incompatible with the active avoidance response. The results of the present ex- periment are not in disagreement with the conditioned response suppression (CRS) interpretation. At longer ITIs responses incompatible with the avoidance response may be extinguished. Whether it is possible to separate the factors characteristic of CRS from those characteristic of conditioned fear as suggested by D'Amato \& Fazzaro (1966) is questionable.

\section{Reterences}

Brush, F. R. The effects of shock intensity on the acquisition and extinction of an avoidance response in dogs. J. comp. physiol. Psychol., 1957, 50, 547-552.

Brush, F. R. The effects of intertrial interval on avoidance learning in the rat. J. comp. physiol. Psychol., 1962, 55, 888-892.

D'Amato, M. R., \& Fazzaro, J. Discriminated lever-press avoidance learning as a function of type and intensity of shock. J. comp. physiol. Psychol., 1966, 61, 313-315.

D'Amato, M. R., Fazzaro, J., \& Etkin, M. Discriminated bar-press avoidance maintenance and extinction in rats as a function of shock intensity. J. comp. physiol. Psychol., 1967, 63, 351-354.

Johnson, J. L., \& Church, R. M. Effects of shock intensity on nondiscriminative avoidance learning of rats in a shuttlebox. Psychon. Sci., 1965, 3, 497-498.

Kimble, G. A. Shock intensity and avoidance learning. $J$. comp. physiol. Psychol.; 1955, 48, 281-284.

Kurtz, P. S. \& Shafer, J. N. Response contingent shock and avoidance conditioning. Psychon. Sci., 1966, 6, 223-224.

Levine, S., \& England, S. J. Temporal factors in avoidance learning. J. comp. physiol. Psychol., 1960, 53, 282-283.

Moyer, K. E., \& Kom, J. H. Effect of UCS intensity on the acquisition and extinction of an avoidance response. J.exp. Psychol., $1964,67,352-359$.

Murphy, J. V., \& Miller, R. E. Spaced and massed practice with a methodological consideration of avoidance conditioning. $J$. exp. Psychol., 1956, 12, 77-80.

Zerbolio, D. J., Jr., Reynierse, J. H., Weisman, R. G., \& Denny, M. R. Pseudoconditioning? J. comp. physiol. Psychol., 1965, 59, $271-274$.

\section{Notes}

1. This investigation was supported in part by grant MH 11634 from National Institutes of Health, United States Public Health Service to J. N. Shafer. Presented at Midwestern Psychological Association, May, 1967.

2. Now at Central Michigan University. 